\title{
Workshop Penulisan Artikel Ilmiah Moda Daring Bagi Guru SMA Kota Surabaya Pada Masa Pandemi Covid-19
}

\author{
Binar Kurnia Prahani 1), Tsuroyya ${ }^{2)}$, Ahmad Wachidul Kohar ${ }^{3)}$, \\ Slamet Setiawan ${ }^{4}$ \\ 1,2,3,4) Universitas Negeri Surabaya \\ binarprahani@unesa.ac.id
}

\begin{abstract}
ABSTRAK: Masih banyak guru berpangkat IV/a yang masih mengalami kesulitan untuk kenaikan pangkat berikutnya karena adanya persyaratan menullis karya tulis ilmiah. Para guru kurang pengetahuan dan kemampuan tentang pembuatan karya tulis ilmiah. Diperkuat adanya tantangan dan masalah yang dihadapi oleh guru terkait berlakunya Peraturan Menteri Negara Pendayagunaan Aparatur Negara dan Reformasi Birokrasi Nomor 16 Tahun 2009 tentang Jabatan Fungsional Guru dan Angka Kreditnya, yang mencantumkan syarat jika naik pangkat harus memiliki publikasi ilmiah. Masalah ini juga berdampak pada Guru SMA di Kota Surabaya yang masih banyak terhambat kenaikan pangkatnya karena tidak bisa menulis artikel di jurnal ilmiah. Kota Surabaya mulai menerapkan pembatasan sosial berskala besar (PSBB). Ini juga berdampak pada pelatihan atau workshop tidak bisa diadakan secara face-to-face. Hal tersebut telah menjadi masalah serius dan perlu alternatif solusi agar kualitas guru SMA di kota Surabaya tidak mengalami penurunan, khususnya keterampilan menulis artikel di jurnal nasional. Oleh karena itu, Gugus Kerjasama, Publikasi, dan Internasionalisai (KPI) Pascasarjana Univeristas Negeri Surabaya (Unesa) memberikan kontribusi positif dan nyata kepada guru SMA di kota Surabaya melalui Kegiatan Workshop Penulisan Artikel Ilmiah Moda Daring Pada Masa Pandemi Covid-19. Kegiatan ini terbukti dapat meningkatkan kualitas dari keterampilan menulis artikel ilmiah.
\end{abstract}

Kata kunci : Moda Daring, Pandemi Covid-19, Penulisan Artikel Ilmiah, Workshop

ABSTRACT: There are still many teachers with rank IV/a who are still having difficulty in getting a promotion to the next rank because of the requirement to write a scientific article. the teachers lack the knowledge and ability in making scientific articles. It is reinforced by the challenges and problems faced by teachers related to the enactment of the Regulation of the Minister of State for the Utilization of State Apparatus and Bureaucratic Reform Number 16 of 2009 concerning Teacher Functional Positions and Credit Score, which states the requirements for advancement to the ranks must have scientific publications. This problem also affects high school teachers in Surabaya who are still hampered by their promotion because they cannot write articles in scientific journals. The large-scale social restriction (PSBB). Has been implemented in Surabaya. This also has an impact on training or workshops that cannot be held face-to-face. This has become a serious problem and an alternative solution is needed so that the quality of high school teachers in the city of Surabaya does not experience a decline, especially the skills to write articles in national journals. Therefore, the Cooperation, Publication, and Internationalization Group (KPI) of Postgraduate School, Universita Negeri Surabaya (Unesa) gave a positive and real contribution to high school teachers in Surabaya through the Workshop on Writing Scientific Articles in Online Mode during the Covid-19 Pandemic. This activity is proven to improve the quality of scientific article writing skills.

Keywords: Online Mode, Covid-19 Pandemic, Writing Scientific Articles, Workshop

\section{PENDAHULUAN}

Kualitas pendidikan di Indonesia umumnya dianggap rendah (OECD, 2015; Purwaningsih et al., 2018). Apa yang paling penting untuk diperbaiki kualitas 
pendidikan adalah untuk meningkatkan kualitas para guru. Untuk tujuan ini, pemerintah Indonesia telah mengambil langkah untuk meningkatkan pelatihan, seperti menawarkan beasiswa untuk meningkatkan kualifikasi guru dan melaksanakan kompetensi penilaian. Ini adalah sebuah proses yang panjang sejak pengetahuan yang mendalam, termasuk pengetahuan yang diperoleh melalui latihan, dan keterampilan yang besar diperlukan untuk itu seorang guru profesional (Nilsson \& Loughran, 2012; Shulman, 1987; van Driel \& Berry, 2017).

Guru profesional memiliki tiga jenis pengetahuan: pengetahuan konten, pengetahuan dan pengetahuan konten pedagogis (PCK) (Etkina, 2010; Williams \& Lockley). Literasi dan budaya literasi juga sangat perlu dimiliki oleh siswa dan guru profesional (Liswati, 2020; Ibda, 2018; Ibda, 2019; Indriyani et al., 2019; Waldfogel, 2012; uslimin, 2018; Odegaard et al., 2014; uryaman, 2015; andasari, 2017; isyah \& Mahanani, 2017; Gunawan dkk., 2018), tanpa adanya literasi dan budaya literasi akan sangat sulit memunculkan budaya menulis, apalagi keterampilan menulis. Perlu dikatahui bahwa keterampilan menulis artikel ilmiah yang juga sangat penting untuk dimiliki guru. Menurut penelitian mutakhir menyebutkan bahwa kemampuan profesional yang harus dimiliki guru salah satunya adalah kemampuan menulis artikel (Aisyah \& Mahanani, 2017; Gunawan dkk., 2018). Guru pada umumnya mengalami kesulitan dalam meningkatkan kemampuan profesional dan akademik dalam bidang kepenulisan, karena para guru belum memiliki wawasan karya ilmiah dan keterampilan yang memadai untuk menulis artikel ilmiah (Aisyah \& Mahanani, 2017; Gunawan dkk., 2018; Suandi, 2008).

Temuan hasil penelitian Gunawan, Triwiyanto, \& Kusumaningrum (2018) menyimpulkan bahwa masih sangat banyak guru berpangkat IV/a yang masih mengalami kesulitan untuk kenaikan pangkat berikutnya karena adanya persyaratan menullis karya tulis ilmiah. Jika mengacu pada temuan tersebut, maka dapat diketahui para guru kurang pengetahuan dan kemampuan tentang pembuatan karya tulis ilmiah. Program pendampingan penulisan artikel ilmiah bagi guru menjadi hal yang krusial dan mendesak untuk dilakukan. Diperkuat adanya tantangan dan masalah yang dihadapi oleh guru terkait berlakunya Peraturan Menteri Negara Pendayagunaan Aparatur Negara dan Reformasi Birokrasi Nomor 16 Tahun 2009 tentang Jabatan Fungsional Guru dan Angka Kreditnya, yang mencantumkan syarat jika naik pangkat harus memiliki publikasi ilmiah. Masalah ini juga berdampak pada Guru SMA di Kota Surabaya yang masih banyak terhambat kenaikan pangkatnya karena tidak bisa menulis artikel di jurnal ilmiah.

Kondisi tersebut diperparah dengan adanya pandemi COVID-19 yang mendera di Indonesia. Menurut BNPB, jumlah kasus positif Corona Virus Disease (COVID-19) di Indonesia kembali bertambah. Dari data 30 April yang dikumpulkan pukul 12.00 WIB, terjadi penambahan 347 kasus positif Corona di Indonesia. Sehingga total kasus positif virus corona mencapai 10.118 orang. Pasien sembuh corona juga terus 
mengalami peningkatan sebanyak 131 orang. Total pasien sembuh saat ini menjadi 1.522 orang. Sedangkan, angka pasien meninggal dunia terus melambat sejumlah 8 orang. Sehingga totalnya menjadi 792 orang. Secara tidak langsung ini berdampak pada guru SMA di kota Surabaya, salah satunya dari sisi keuangan. Di masa pandemi COVID-19 ini, khususnya para guru di SMAN 13 Surabaya dan SMA Al Hikmah Surabaya mengalami keterbatasan anggaran untuk mengikuti workshop pelatihan penulisan artikel ilmiah yang harus berbayar. Menurut mayoritas guru yang telah diobservasi berpendapat bahwa daripada untuk pelatihan penulisan artikel ilmiah lebih baik untuk keperluan dan kebutuhan yang lebih penting.

Kota Surabaya, Kabupaten Sidoarjo, dan Kabupaten Gresik mulai menerapkan pembatasan sosial berskala besar (PSBB) mulai Selasa (28/4/2020). Ini juga berdampak pada pelatihan atau workshop tidak bisa diadakan secara face-to-face. Hal tersebut telah menjadi masalah serius dan perlu alternatif solusi agar kualitas guru SMA di kota Surabaya tidak mengalami penurunan, khususnya keterampilan menulis artikel di jurnal nasional. Oleh karena itu, Gugus Kerjasama, Publikasi, dan Internasionalisai (KPI) Pascasarjana Univeristas Negeri Surabaya (Unesa) memberikan kontribusi positif dan nyata kepada guru SMA di kota Surabaya melalui kegiatan workshop penulisan artikel ilmiah moda daring pada masa pandemi Covid-19.

\section{PERMASALAHAN}

Mengacu kepada butir analisis situasi, permasalahan mitra khususnya di SMAN 13 Surabaya dan SMA Al Hikmah Surabaya mencakup hal- hal berikut ini.

1. Para guru di SMAN 13 Surabaya dan SMA Al Hikmah Surabaya mengalami kesulitan untuk menulis karya dalam bentuk artikel ilmiah yang berkualitas.

2. Para guru di SMAN 13 Surabaya dan SMA Al Hikmah Surabaya masih kebingungan untuk aktif dan produktif melakukan kegiatan publikasi di jurnal ilmiah.

3. Di masa pandemi COVID-19 ini, para guru di SMAN 13 Surabaya dan SMA Al Hikmah Surabaya mengalami keterbatasan anggaran untuk mengikuti workshop pelatihan penulisan artikel ilmiah yang berbayar.

\section{METODE PELAKSANAAN}

Solusi yang ditawarkan untuk menyelesaikan permasalahan yang dihadapi mitra khususnya di SMAN 13 Surabaya dan SMA Al Hikmah Surabaya secara sistematis sesuai dengan prioritas permasalahan meliputi:

1. Para guru di SMAN 13 Surabaya dan SMA Al Hikmah Surabaya yang mengalami kesulitan untuk menulis karya dalam bentuk artikel ilmiah yang berkualitas. Solusi nyata dari peneliti adalah para guru dilatih untuk membuat artikel ilmiah yang berkualitas melalui kegiatan Workshop Penulisan Artikel Ilmiah Moda Daring. 
2. Para guru di SMAN 13 Surabaya dan SMA Al Hikmah Surabaya masih kebingungan untuk aktif dan produktif melakukan kegiatan publikasi di jurnal ilmiah. Solusi nyata dari peneliti adalah para guru dilatih untuk submit artikel ilmiah di Jurnal Penelitian Pendidikan dan Pembelajaran melalui kegiatan Workshop Penulisan Artikel Ilmiah Moda Daring.

3. Masa pandemi COVID-19 ini, para guru di SMAN 13 Surabaya dan SMA AlHikmah Surabaya mengalami keterbatasan anggaran untuk mengikuti workshop pelatihan penulisan artikel ilmiah yang berbayar. Solusinya dengan kegiatan Workshop Penulisan Artikel Ilmiah Moda Daring yang gratis.

Workshop Penulisan Artikel Ilmiah Moda Daring Bagi Guru SMA Kota Surabaya pada Masa Pandemi COVID-19 dengan agenda sebagai berikut.

1. Penyampaian Materi Penulisan Artikel Ilmiah Moda Daring Bagi Guru SMA.

2. Pengerjaan Tugas oleh Peserta Workshop Penulisan Artikel Ilmiah Moda Daring.

3. Presentasi Hasil Penugasan Artikel Ilmiah

4. Konsultasi Mandiri

5. Finalisasi Hasil Penulisan Artikel Ilmiah

6. Pendampingan Submit Hasil Penulisan Artikel Ilmiah.

Kepakaran yang diperlukan dalam menyelesaikan seluruh persoalan atau kebutuhan mitra meliputi:

1. Mampu menulis artikel ilmiah yang berkualitas.

2. Mampu melakukan publikasi di Jurnal Ilmiah.

3. Mampu melatih peserta workshop penulisan artikel ilmiah moda daring di masa pandemi COVID-19.

\section{PELAKSANAAN}

Pelaksanaan kegiatan menjelaskan tahapan atau langkah-langkah dalam melaksanakan solusi yang ditawarkan untuk mengatasi permasalahan yang memuat halhal berikut ini.

1. Tahapan atau langkah-langkah yang ditempuh guna melaksanakan solusi atas permasalahan spesifik yang dihadapi oleh mitra khususnya di SMAN 13 Surabaya dan SMA Al Hikmah Surabaya yang terdampak pandemi COVID 19. Pelaksanaan solusi dibuat secara sistematis yang meliputi segi kesehatan, ekonomi, sosial, budaya, keagamaan, mutu layanan atau kehidupan bermasyarakat seperti pada Gambar 1. 
Penyampaian Materi

Penulisan Artikel

Ilmiah Moda Daring

Bagi Guru SMA
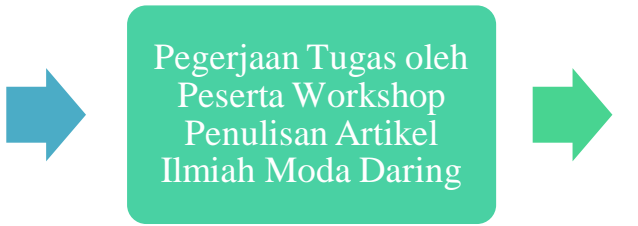

Presentasi Hasil

Penugasan Artikel Ilmiah
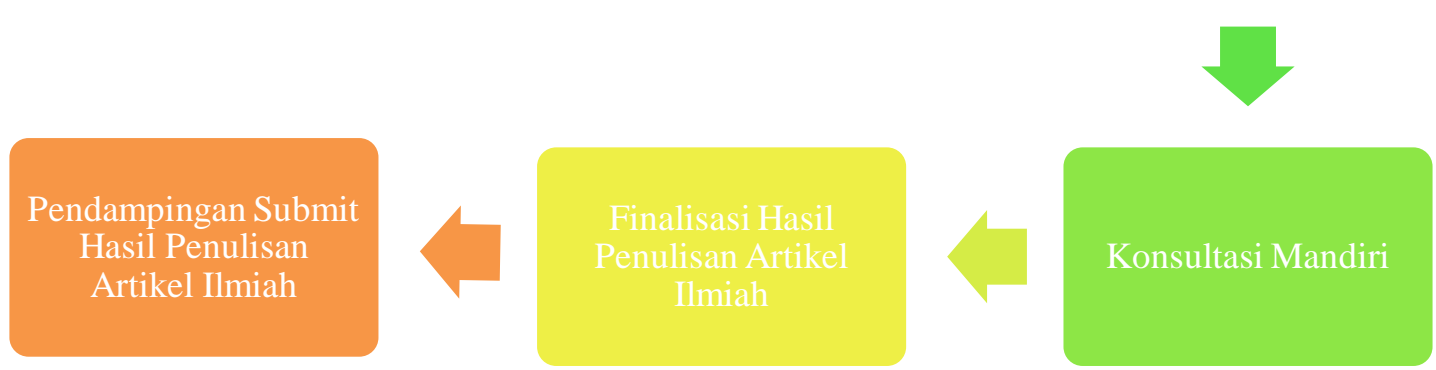

Gambar 1. Tahapan Pelaksanaan PKM

2. Uraian metode pendekatan yang ditawarkan untuk menyelesaikan persoalan yang telah disepakati bersama dengam mitra disajikan pada Gambar 2 .

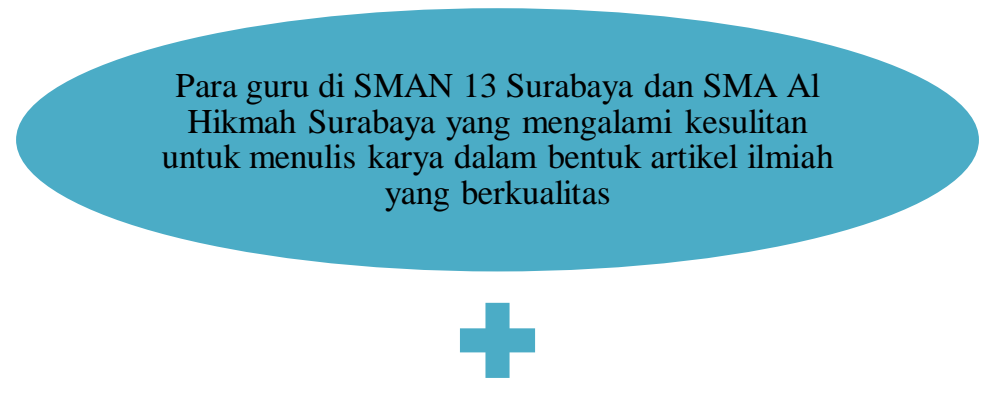

Para guru di SMAN 13 Surabaya dan SMA Al

Hikmah Surabaya masih kebingungan untuk aktif dan produktif melakukan kegiatan publikasi di jurnal ilmiah

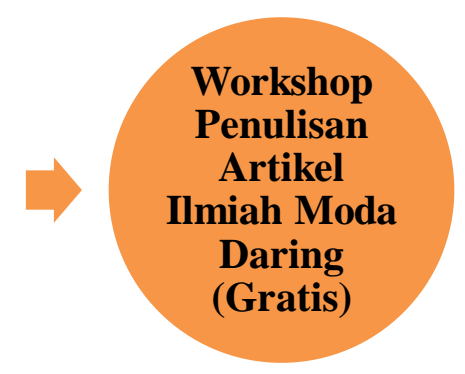

Di era pandemic COVID-19 ini, para guru di

SMAN 13 Surabaya dan SMA Al Hikmah

Surabaya mengalami keterbatasan anggaran untuk mengikuti workshop pelatihan penulisan artikel ilmiah yang berbayar

\section{Gambar 2. Metode yang digunakan dalam pelaksanan PKM}




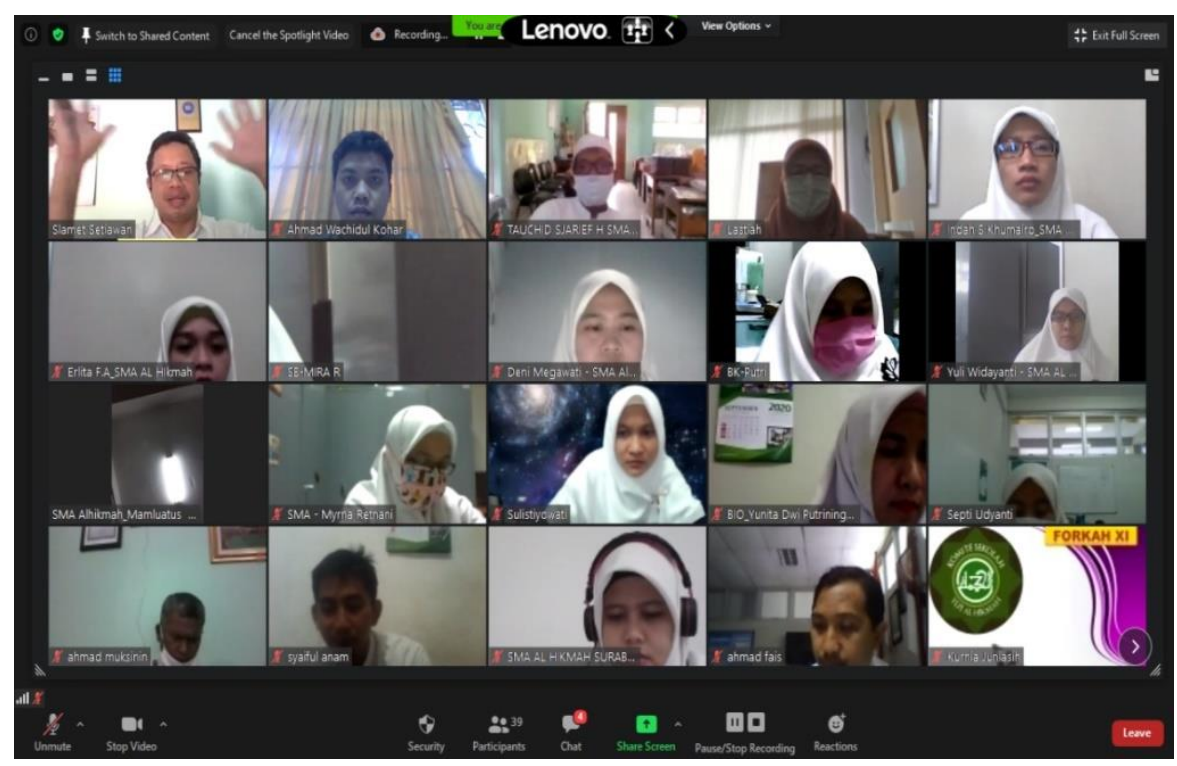

Gambar 3. Pelaksanaan workshop menggunakan zoom

3. Pelaksanaan kegiatan workshop dilakukan dalam dua tahap. Penjelasan masingmasing tahap dijelaskan sebagai berikut.

Workshop Tahap 1:

Materi 1: Menggali ide penelitian, Penyusunan artikel ilmiah standard IMRAD

Materi 2: Analisis Artikel Ilmiah (PTK, best practice)

Workshop Tahap 2:

Materi 3: Analisis draf artikel hasil penugasan (1) (Matematika), Analisis draf artikel hasil penugasan (2) (IPA), Analisis draf artikel hasil penugasan (2) (IPS), Analisis draf artikel hasil penugasan (3) (Bahasa)

Materi 4: Proses penerbitan artikel ilmiah, kategorisasi jurnal, proses telaah artikel, menanggapi hasil review, Pengenalan cara submit artikel ke jurnal ilmiah.

\section{HASIL DAN LUARAN}

Partisipasi mitra dalam pelaksanaan program ini meliputi: (a) Pimpinan mitra menyediakan fasilitas untuk para guru yang kesulitan menggunakan Webinar (yang disepakati bersama) untuk mengikuti Workshop Penulisan Artikel Ilmiah Moda Daring; (b) Pimpinan mitra mendukung penuh kegiatan Workshop Penulisan Artikel Ilmiah Moda Daring; (c) Mitra harus memiliki semangat dan antusias yang tinggi dalam mengikuti Workshop Penulisan Artikel Ilmiah Moda Daring; (d) Mitra menyediakan draft artikel ilmiah yang akan digunakan dalam Workshop Penulisan Artikel Ilmiah Moda Daring. 


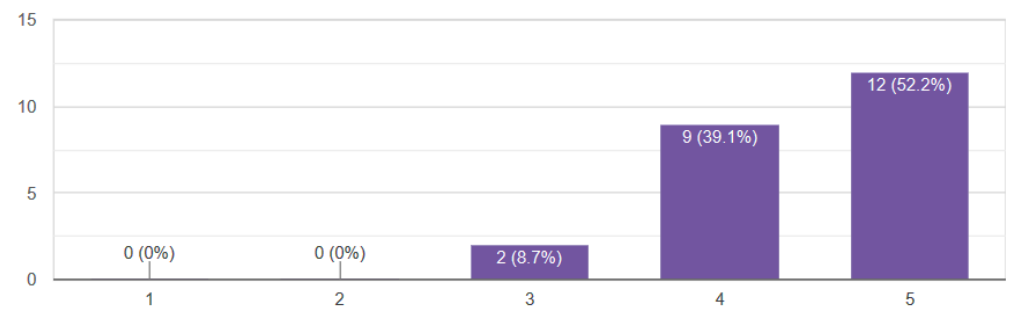

Gambar 4. Grafik respon relevansi materi workshop dengan peningkatan kualitas artikel peserta

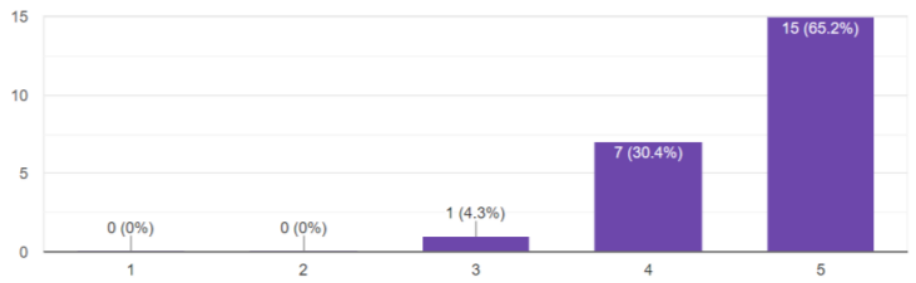

Gambar 5. Grafik Respon kualitas telaah hasil review penyajian pemateri workshop

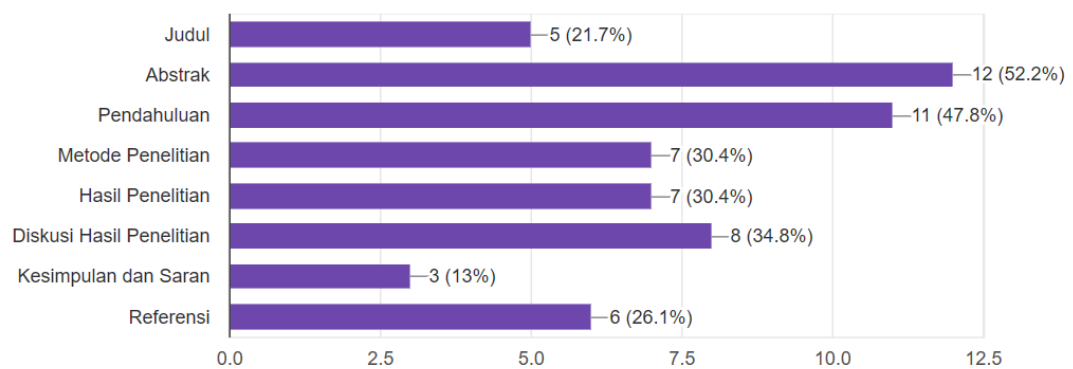

Gambar 6. Grafik Respon Kualitas Artikel Peserta

Gambar 4), 5), dan 6) menunjukkan bahwa PKM ini dinyatakan berhasil. Selain itu, keberhasilan PKM ini diperkuat karena telah memenuhi syarat berikut ini: (a) Peserta Workshop Penulisan Artikel Ilmiah Moda Daring diikuti minimal 20 guru SMA kota Surabaya; (b) Peserta Workshop Penulisan Artikel Ilmiah Moda Daring memberikan respon dalam kategori minimal cukup positif ( $\geq 50 \%$ ); (c) Produk 7 artikel yang berhasil disubmit di Jurnal Nasional (Jurnal Penelitian Pendidikan dan Pembelajaran).

\section{KESIMPULAN}

PKM ini dilakukan dengan moda Daring menggunakan Zoom sebagai bentuk solusi keterbatasan di masa pandemi Covid-19 telah terbukti efektif melatihkan keterampilan menulis dan submit artikel di jurnal ilmiah. Keberlanjutan program PKM ini adalah mitra akan mendapatkan banyak manfaat antara lain kemampuan menulis artikel ilmiah dan publikasi di jurnal ilmiah. Keberlanjutan program PKM ini dapat 
dilacak dari jumlah artikel dari peserta yang siap published di jurnal nasional. Ketika ada peserta yang berhasil published, maka ini akan menjadi katalis bagi peserta lain dalam kegiatan publikasi artikel di jurnal ilmiah. Untuk hilirisasi kepakaran dalam bidang Publikasi di masyarakat umum, maka di tahun 2020 ini Gugus KPI telah melakukan kegiatan PKM di lingkungan Guru SMA Kota Surabaya. Khususnya di masa pandemi COVID-19 ini, banyak guru yang memerlukan workshop pelatihan penulisan artikel ilmiah secara daring dan gratis. Diharapkan dengan adanya PKM ini, kinerja KPI semakin terlihat nyata dan memberikan dampak positif secara langsung dalam peningkatan kualitas Guru SMA Kota Surabaya, khususnya penulisan artikel ilmiah yang saat ini sangat diperlukan oleh mitra.

\section{DAFTAR PUSTAKA}

Aisyah, E.N., dan Mahanani, P. 2017. Pelatihan menulisan artikel ilmiah bagi guru sekolah dasar dan taman kanak-kanak kecamatan Tajinan kabupaten Malang. Abdimas Pedagogi, 1(1), p. 22-26.

Etkina, E. 2010. Pedagogical content knowledge and preparation of high school physics teachers. Physical Review Physics Education Research, 6(2), p. 1-26.

Gunawan, I., Triwiyanto, T., dan Kusumaningrum, D.E. 2018. Pendampingan penulisan artikel ilmiah bagi para guru sekolah menengah pertama. ABDIMAS PEDAGOGI: Jurnal Ilmiah Pengabdian kepada Masyarakat, 1(2), p. 128-135.

Ibda, H. 2018. Penguatan literasi baru pada guru madrasah ibtidaiyah dalam menjawab tantangan era revolusi industri 4.0. JRTIE: Journal of Research and Thought of Islamic Education, I, p. 1-21.

Ibda, H. 2019. Pembelajaran bahasa indonesia berwawasan literasi baru di perguruan tinggi dalam menjawab tantangan era revolusi industri 4.0. Jalabahasa, 15(1), p. 48-64.

Indriyani, V., Zaim, M., Atmazaki, \& Ramadhan, S. 2019. Literasi baca tulis dan inovasi kurikulum bahasa. Jurnal Keilmuan Bahasa, Sastra, dan Pengajarannya. 5(1), p. 108-118.

Liswati, T.W. 2020. Blended Formula Four Di (4D) with actor network theory to increases the outcome of literacy culture. IJORER: International Journal of Recent Educational Research, 1(1), p. 30-38.

Muslimin. 2018. Foster a culture of literacy through increased reading interest in village communities. Cakrawala Pendidikan, 37(1), p. 107-118.

Nilsson, P. and Loughran, J. 2012. Exploring the development of pre-service science elementary teachers' pedagogical content knowledge. Journal of Science Teacher Education, 23(7), p. 699-721.

Odegaard, M., Haug, B., Mork, S., \& Sorvik, G.O. 2014. Budding science and literacy. A classroom video study of the challenges and support in an integrated inquiry and literacy teaching model. Procedia-Social and Behavioral Sciences, 167, p. 274-278.

OECD. 2015. Education in Indonesia: Rising to the Challenge. Paris: OECD Publishing. 
Purwaningsih, E., Wasis, Suyatno, and Nurhadi, D. 2018. Innovative lesson study (LS) to improve the pedagogical content knowledge (PCK) of STEM teacher candidates in Indonesia. Global Journal of Enginerring. Education. 20(1), p. 3947.

Shulman, L. 1987. Knowledge and teaching: foundations of the new reform. Harvard Educational Review, 57(1), p. 1-23.

Suandi, I.N. 2008. Gerakan menulis karya ilmiah (sebuah upaya peningkatan profesionalisme guru). Jurnal Pendidikan dan Pengajaran UNDIKSHA, 41(1), p. $510-531$.

Suryaman, M. 2015. Analisis hasil belajar peserta didik dalam literasi membaca melalui studi internasional (PIRLS) 2011. Jurnal LITERA, 14(1), p. 170-186.

van Driel, J.H. and Berry, A.K. 2017. Developing Pre-Service Teachers' Pedagogical Content Knowledge. In: Clandinin, D. J. and Husu, J. (Eds), The SAGE Handbook of Research on Teacher Education. California: Sage Publications Inc.

Waldfogel J. 2012. The role of out-of-school factors in the literacy problem. The Future of Children, 22(2), p. 40-54.

Wandasari, Y. 2017. Implementasi gerakan literasi sekolah (GLS) sebagai pembentuk pendidikan karakter. Jurnal Manajemen, Kepemimpinan, dan Supervisi Pendidikan, 1(1), p. 325-342.

Williams, J., and Lockley, J. 2012. Using CoRes to develop the pedagogical content knowledge (PCK) of early career science and technology teachers. Journal of Technology Education, 24(1), p. 34-53. 
Volume 4, Nomor 2, September 2020 